Original Contribution

\title{
STUDY OF GENETIC PARAMETERS AND ASSOCIATION BETWEEN CHARACTERS IN EINKORN GENOTYPES
}

\author{
G. Desheva*, B. Kyosev \\ Department of Plant Genetic Resources, Institute of Plant Genetic Resources "Konstantin Malkov", \\ Sadovo, Bulgaria
}

\begin{abstract}
The study is carried out in the experimental field of Institute of Plant Genetic Resources "Konstantin Malkov"-Sadovo, Bulgaria during 2013-2015 growing seasons. Twenty two einkorn wheat accessions were evaluated to estimate of variability, heritability, genetic advance and associations among characters. The values of mean square for all twelve characters showed highly significant differences between einkorn genotypes. The phenotypic coefficients of variation were higher than genotypic coefficient of variation (GCV). High heritability accompanied with moderate expected genetic advances was recorded for number of spikelets per spike. High values for the genetic advance expressed as a percentage of the mean and moderate values for the heritability in broad sense were observed in the traits total number of tillers per plan and number of productive tillers per plant. The number of productive tillers per plant, grain weight per spike and spike length without awns had the strongest direct effect on grain yield per plant. The total number of tillers per plant had the highest negative direct effect on the grain yield per plant. Stepwise multiple linear regression analysis revealed that three traits included grain weight per spike, number of productive tillers per plant and total number of tillers per plant with $\mathrm{R} 2=85.30 \%$, had justified the best prediction model.
\end{abstract}

Key words: einkorn, variability, genetic advance, heritability, correlation, pat analysis, stepwise regression

\section{INTRODUCTION}

Einkorn (Triticum monococcum L.) is an old cereal known to have been grown 9000 years ago, and its use extended to the Balkans and Central Europe in the neolithic period (1). It is very useful and promising plant breeding material for its resistance to disease (rusts, powdery mildew) (1-8). The crop is suitable for low input systems - organic farming because of its better adaptability in marginal areas (in comparison with other crops) $(1,9)$. Einkorn is also valued for unique quality of grain and simple genome, which can provide an easy way to identify toxic fraction causing celiac disease. Grain contains 16-28 \% of protein, 3-6 times more carotenoids than polyploid wheats and no anti-nutritious compounds (10-16). The attention toward this ancient species has also been renewed by the increasing demand for traditional products, the request for species suitable to be grown in marginal areas and the need to preserve genetic

\footnotetext{
*Correspondence to: Gergana Desheva, Department: "Plant Genetic Resources", Institute of Plant Genetic Resources "Konstantin Malkov", 2 Druzhba Str., 4122Sadovo, Bulgaria, email:gergana_desheva@abv.bg
}

diversity and to develop new genotypes between interspecific crosses (9).

Study of statistical parameters as mean, variance, heritability, genetic advance , etc., is not only to evaluate the genetic stability and performance of any particular genotype but it is also a measure to determine the effectiveness of selection for a particular trait in that genotype. Wider range of variability makes it convenient to select a particular trait with ease and efficacy (17). Variability studies are limited in einkorn wheat. It is fact that the higher the variability among the genotypes betters the chances for further improvement in the crop (18). Heritability estimates provide an indication of the expected response to selection in a population. Information on the nature and magnitude of heritability in a population is one of the prerequisites for successful breeding programs in selecting genotypes with desirable characters (19). High heritability indicates less environmental influence in the observed variation (20). High heritability (broad sense) associated with high genetic advance reveals strong contribution of additive genetic variance for expression of the traits and offers the most effective condition for selection $(21,22)$. 
Phenotypic and genotypic coefficients of variations, heritability and genetic advance have been used to assess the magnitude of variance in wheat breeding material (23). Correlation and path coefficient analysis are used as an important tool to bring information about appropriate cause and effects relationship between yield and some yield components $(24,25)$. Therefore the present study was designed to estimate the degree of genetic variability, heritability, genetic advance and associations among characters in 22 einkorn wheat genotypes.

\section{MATERIAL AND METHODS}

The study is carried out in the experimental field of Institute of Plant Genetic Resources "Konstantin Malkov"-Sadovo, Bulgaria during 2013-2015 growing seasons. Twenty two einkorn wheat accessions were examined. The accessions were sown in harvest plots each of $1 \mathrm{~m}^{2}$ in three replications, in the randomized block design. Each plot consisted of five rows of $1.0 \mathrm{~m}$ length with $20 \mathrm{~cm}$ and $5 \mathrm{~cm}$ spacing between and within rows, respectively. All the agronomical packages and practices were applied to raise healthy crop. At the time of maturity, ten competitive plants of each genotype from each replication were randomly selected. Data were registered for length of second leaf $(\mathrm{cm})$, width of second leaf $(\mathrm{cm})$, total number of tillers per plant, number of productive tillers per plant, plant height $(\mathrm{cm})$, spike length with awn $(\mathrm{cm})$, spike length without awn $(\mathrm{cm})$, number of spikelets per spike, number of grains per spike, grain weight per spike $(\mathrm{g})$, thousand grain weight and grain yield per plant $(\mathrm{g})$.

The mean data from all eight characters were used to analysis of variance according to Lidansky (26). Ecological, genotypic and phenotypic variances, genotypic and phenotypic coefficient of variability, broad sense heritability were calculated according to Singh and Chaudhary (27). Genetic advance in terms of percentage of means was assessed by Brim et al. (28). Phenotypic correlations were calculated by using phenotypic variances and covariance. Correlation coefficients were calculated as followed by Lidansky (26) whereas path coefficient analysis was conducted to Dewey \& Lu (29) using phenotypic correlations to assess direct and indirect influences of different yield components on grain yield per plant. Stepwise regression analysis was applied for determination of the best model, which accounted for variation exists in grain yield as dependent variable. Statistical analyses were performed using the statistical program SPSS 13.0.

\section{RESULTS AND DISCUSSION \\ Analysis of variance, heritability in broad sense and genetic advance expressed as percentage of mean}

Variability plays an important role in crop breeding. An insight into the magnitude of variability present in crop species is of utmost importance as it provides the basis for selection (30). Highly significant differences and wide ranges of variation for all characters indicated the presence of sufficient variability among the genotypes (31-33).

In present study, 22 genotypes of einkorn wheat were studied to assess their genetic potential. The analysis of variance is presented in Table 1. Coefficient of variation ranged from 5.79 to $20.86 \%$. The most relative variable character during the period of study was total number of tillers per plant (20.86\%), following to number of productive tillers per plant $(19.23 \%)$ and grain yield per plant $(18.01 \%)$. The values of these coefficients confirm that these traits are more susceptible to change under the influence of different factors (34). Relatively the least variable for the period of study indicated plant height (5.79\%) (Table 1).

Table 1. Analysis of variance for various quantitative traits in einkorn wheat genotypes

\begin{tabular}{lcccccccc}
\hline \multicolumn{1}{c}{ Trait } & $\mathbf{N}$ & Minimum & Maximum & Mean & $\begin{array}{c}\text { Std. } \\
\text { Deviation }\end{array}$ & Variance & $\begin{array}{c}\mathbf{C V}, \\
\text { \% }\end{array}$ & MS \\
\hline LSL & 22 & 20.68 & 27.58 & 23.06 & 1.78 & 3.18 & 7.73 & $57.2^{*}$ \\
\hline WSL & 22 & 0.96 & 1.45 & 1.16 & 0.13 & 0.02 & 10.96 & $0.29^{* * *}$ \\
\hline TNTP & 22 & 12.67 & 25.53 & 18.08 & 3.77 & 14.21 & 20.86 & $255.81^{* * *}$ \\
\hline NPTP & 22 & 10.50 & 19.67 & 14.39 & 2.77 & 7.66 & 19.23 & $137.88^{* * *}$ \\
\hline PH & 22 & 112.10 & 139.43 & 124.16 & 7.19 & 51.76 & 5.79 & $983.46^{* * *}$ \\
\hline SLWA & 22 & 14.40 & 19.81 & 16.63 & 1.35 & 1.83 & 8.12 & $32.85^{* * *}$ \\
\hline SLWOA & 22 & 7.17 & 10.11 & 8.73 & 0.78 & 0.61 & 8.99 & $11.069^{* * *}$ \\
\hline NSS & 22 & 31.05 & 42.03 & 36.19 & 3.30 & 10.92 & 9.13 & $196.49^{* * *}$ \\
\hline NGS & 22 & 29.77 & 40.70 & 35.53 & 3.35 & 11.19 & 9.42 & $201.49^{* * *}$ \\
\hline GWS & 22 & 0.57 & 1.03 & 0.74 & 0.13 & 0.02 & 17.24 & $0.29^{* * *}$ \\
\hline GYP & 22 & 4.82 & 10.09 & 7.45 & 1.34 & 1.80 & 18.01 & $32.35^{* * *}$ \\
\hline TGW & 22 & 20.00 & 32.50 & 24.90 & 3.06 & 9.38 & 12.30 & $168.91^{* * *}$ \\
\hline
\end{tabular}


DESHEVA G., et al.

The values of mean square for all twelve characters showed highly significant differences between einkorn accessions (Table 1). This means the existence of a high degree of genetic variability in the material to be exploited in breeding program $(20,35,36)$.

Environmental variances ranged from 0.06 (grain weight per spike) to 39.72 (plant height). Genotypic variance varied between 0.01 (width of second leaf and grain weight per spike) and 52.43 (plant height). Relatively the highest phenotypic variance values of 92.21 for plant height, 39.77 for number of grain per spike and 39.57 for total number of tillers per plant were recorded in the study (Table 2).

Table 2. Genetic parameters of various yield components of 22 einkorn wheat genotypes

\begin{tabular}{lccccccc}
\hline \multicolumn{1}{c}{ Trait } & EV & GV & PhV & GCV & PhCV & $\begin{array}{c}\text { H, } \\
\text { \% }\end{array}$ & $\begin{array}{c}\text { GAM, } \\
\text { \% }\end{array}$ \\
\hline LSL & 35.31 & 1.22 & 36.52 & 4.78 & 26.20 & 3.33 & 1.80 \\
\hline WSL & 0.10 & 0.01 & 0.11 & 8.94 & 28.32 & 9.97 & 5.82 \\
\hline TNTP & 26.85 & 12.72 & 39.57 & 19.73 & 34.80 & 32.15 & 23.04 \\
\hline NPTP & 15.24 & 6.81 & 22.05 & 18.14 & 32.63 & 30.90 & 20.77 \\
\hline PH & 39.78 & 52.43 & 92.21 & 5.83 & 7.73 & 56.86 & 9.06 \\
\hline SLWA & 1.93 & 1.72 & 3.64 & 7.88 & 11.48 & 47.15 & 11.15 \\
\hline SLWOA & 0.92 & 0.56 & 1.48 & 8.61 & 13.94 & 38.10 & 10.94 \\
\hline NSS & 6.93 & 10.53 & 17.46 & 8.97 & 11.55 & 60.31 & 14.35 \\
\hline NGS & 30.25 & 9.51 & 39.77 & 8.68 & 17.75 & 23.92 & 8.75 \\
\hline GWS & 0.05 & 0.01 & 0.07 & 15.58 & 34.98 & 19.83 & 14.29 \\
\hline GYP & 7.81 & 1.36 & 9.17 & 15.68 & 40.67 & 14.87 & 12.46 \\
\hline TGW & 13.56 & 8.63 & 22.19 & 11.80 & 18.92 & 38.89 & 15.16 \\
\hline
\end{tabular}

Genotypic and phenotypic coefficients of variation are used to measure the variability that exists in a given population (23). Deshmukh et al. (37) classified $\mathrm{PhCV}$ and GCV values as high $(>20 \%)$, moderate $(10-$ $20 \%)$ and low $(<10 \%)$. In the present study high PhCV and moderate GCV were observed in traits: total number of tillers per plant $(\mathrm{GCV}=19.73 \%, \mathrm{PhCV}=34.80 \%)$, number of productive tillers per plant $(\mathrm{GCV}=18.14 \%$, $\mathrm{PhCV}=32.63 \%$ ), grain weight per spike $(\mathrm{GCV}=15.58 \%$, $\mathrm{PhCV}=34.98 \%)$, grain yield per plant $(\mathrm{GCV}=15.68 \%, \mathrm{PhCV}=40.67 \%)$. Moderate PCV and GCV were found for thousand grain weight $(\mathrm{GCV}=11.80 \%$ and $\mathrm{PhCV}=18.92 \%$ ). Moderate $\mathrm{PhCV}$ and low GCV were recorded for spike length with awns $(\mathrm{GCV}=7.88 \%$ and $\mathrm{PhCV}=11.48 \%)$, spike length without awns (GCV $=8.61 \%$ and $\mathrm{PhCV}=13.94 \%$ ), number of spikelets per spike ( $\mathrm{GCV}=8.97 \%$ and $\mathrm{PhCV}=11.55 \%$ ), number of grain per spike $(\mathrm{GCV}=8.68 \%$ and $\mathrm{PhCV}=17.75 \%$ ). Low PhCV and GCV showed plant height $(\mathrm{GCV}=5.83 \%$ and $\mathrm{PhCV}=7.73 \%)$. Low GCV and high PhCV were registered for length and width of second leaf (Table 2). The $\mathrm{PhCV}$ values were higher than GCV values for all the traits which reflect the influence of environment on the expression of traits (33, 38-40).

Heritability estimates provide the information about index of transmissibility of the quantitative characters of economic importance and are essential for an effective crop breeding strategy. The magnitude of heritability also helps in predicting the behavior of succeeding generations by devising the appropriate selection criteria and assessing the level of genetic improvement $(36,41)$. The higher the heritability estimates, the simpler are the selection procedures (25). In our study high estimates of heritability in broad sense (above $60 \%$ ) were recorded for number of spikelets per spike $-60.31 \%$ (Table 2). According to Gashaw et al. (2010) characters with high heritability are predominantly controlled by genetic factors. Thus, we could anticipate genetic advance under selection for these characters from different types and intensities of selection. Moderate broad sense heritability estimates (30-60\%) were exhibited for total and productive tillers per plant $(32.15 \%$ and $30.90 \%$ ), plant height (56.86\%), spike length with and without of awns $(47.15 \%$ and $38.10 \%)$ and thousand grain weight (38.89\%) which suggested that selection should be delayed to more advance generations for these traits (40). Low heritability $(<30 \%)$ was recorded for length and width of second leaf (3.33\% and 9.97\%), number of grain per spike (23.92\%), grain weight per spike $(19.83 \%)$ and grain yield per plant (14.87\%) (Table 2). According to the same authors this implies that selection may be considerably difficult due to the masking effect of the environment for these traits.

The expected genetic advance expressed as a percentage of the mean varied between $1.80 \%$ 
DESHEVA G., et al.

and $23.04 \%$. Genetic advance as percentage of mean was high for total number of tillers per plant $(23.04 \%)$ followed by number of productive tillers per plant $(20.77 \%)$. It was moderate for spike length with and without of awns $(11.15 \%$ and $10.94 \%)$, number of spikelets per spike $(14.35 \%)$, grain weight per spike (14.29\%), grain yield per plant (12.46\%) and thousand grain weight $(15.16 \%)$. The low genetic advance was recorded for the remaining traits (length and width of second leaf, plant height and number of grain per spike) (Table 2).

The heritability value alone provides no indication of the amount of genetic progress that would result in selecting the best individual, but heritability estimates along with the genetic advance is considered more useful $(41,42)$. In this study high heritability accompanied with moderate expected genetic advances in the case of number of spikelets per spike indicated that most likely the heritability was due to additive gene effect and selection may be effective in early generations for this trait (40). High values for the genetic advance expressed as a percentage of the mean and moderate values for the heritability in broad sense were observed in the traits total number of tillers per plan and number of productive tillers per plant. Moderate estimate for both heritability and genetic advance was registered for spike length with awns, spike length without awns and thousand grain weight. Moderate heritability accompanied with low expected genetic advances was computed for plant height. Low heritability coupled with moderate genetic advance was observed for grain weight per spike and grain yield per plant. Low values for both heritability and genetic advance were recorded for length of second leaf, width of second leaf and number of grain per plant that may be due of the presence of non-additive type of genetic action.

\section{Associations among characters}

Grain yield is a complex trait influenced by a number of yield contributing traits. Information on the association of morphoagronomic traits with grain yield forms a basis for any successful breeding programme (43). Pearson's correlation coefficients between twelve characters are presented in Table 3. Number of productive tillers per plant showed significant negative and positive correlation with width of second leaf $\left(-0.460^{*}\right)$ and total number of tillers per plant $(0.969 * *)$. Plant height correlated positively with length of second leaf $\left(0.460^{*}\right)$ and negatively with both total and productive number of tillers per plant $\left(-0.506^{*},-0.496^{*}\right)$. Spike length without awns was in positive relationship with spike length with awns $\left(0.625^{* *}\right)$ at $\mathrm{p} \leq 0.01$. Number of spikelets per spike correlated negatively with length of second leaf $\left(-0.463^{*}\right)$ and positively with spike length without awn $\left(0.693^{* *}\right)$. Number of grain per spike showed significant positive correlations with spike length without awn $\left(0.705^{* *}\right)$ and number of spikelets per spike 0.679). The correlation between grain yield per plant and grain weight per spike was positive and significant at the 0.01 level $(0.607 * *)$. The relationships between thousand grain weight, number of spikelets per spike, grain weight per spike and grain yield per plant were also significantly $\left(-0.606 * *, 0.748^{* *}\right.$ and $0.472 *$ ) (Table 3). Increase of thousand grain weight is associated with decrease of number of spikelets per spike and increase of grain weight per spike and grain yield per plant.

Table 3. Phenotypic correlation coefficients of investigated characters in einkorn wheat

\begin{tabular}{|c|c|c|c|c|c|c|c|c|c|c|c|c|}
\hline & LSL & WSL & TNTP & NPTP & PH & SLWA & $\begin{array}{l}\text { SLWO } \\
\text { A }\end{array}$ & NSS & NGS & GWS & GYP & TGW \\
\hline LSL & 1 & & & & & & & & & & & \\
\hline WSL & -0.064 & 1 & & & & & & & & & & \\
\hline TNTP & -0.097 & -0.377 & 1 & & & & & & & & & \\
\hline NPTP & -0.084 & $-0.460 *$ & $0.969 * *$ & 1 & & & & & & & & \\
\hline $\mathrm{PH}$ & $0.460 *$ & 0.032 & $-0.506^{*}$ & $-0.496 *$ & 1 & & & & & & & \\
\hline SLWA & 0.213 & 0.245 & -0.275 & -0.272 & 0.087 & 1 & & & & & & \\
\hline SLWOA & -0.029 & 0.102 & -0.089 & -0.103 & 0.283 & $0.625^{* *}$ & 1 & & & & & \\
\hline NSS & $-0.463^{*}$ & 0.260 & 0.075 & 0.035 & -0.089 & 0.261 & $0.693 * *$ & 1 & & & & \\
\hline NGS & -0.204 & 0.131 & -0.105 & -0.078 & 0.151 & 0.258 & $0.705 * *$ & $0.679 * *$ & 1 & & & \\
\hline GWS & 0.015 & -0.068 & -0.223 & -0.149 & 0.208 & -0.103 & -0.043 & -0.160 & 0.316 & 1 & & \\
\hline GYP & -0.031 & -0.401 & 0.401 & $0.534 *$ & -0.128 & -0.221 & -0.013 & -0.093 & 0.183 & $0.607 * *$ & 1 & \\
\hline TGW & 0.323 & -0.136 & -0.218 & -0.148 & 0.168 & -0.197 & -0.381 & $-0.606 * *$ & -0.249 & $0.748 * *$ & $0.472 *$ & 1 \\
\hline
\end{tabular}

*Correlation is significant at the 0.05 level (2-tailed).

$* *$ Correlation is significant at the 0.01 level (2-tailed).

Correlation studies along with path analysis provide a better understanding of the association of different characters with grain yield. Path coefficient analysis measures the 
DESHEVA G., et al.

direct influence of one variable upon the other, and permits separation of correlation coefficients into components of direct and indirect effects. Portioning of total correlation into direct and indirect effects provide actual information on contribution of characters and thus form the basis for selection to improve the yield (44). In our study of path coefficient analysis, grain yield represented the dependent variable and the remaining estimated characters (length of second leaf, width of second leaf, total number of tillers per plant, number of productive tillers per plant, plant height, spike length with awn, spike length without awn, number of spikelets per spike, number of grains per spike, grain weight per spike, thousand grain weight and grain yield per plant) were the independent ones. Direct and indirect effects of these components determined on grain yield and their contribution ratios were presented in Table 4.

Table 4. Direct (Bold and Underline) and indirect effect of 11 characters (independent variables) on grain yield per plant (dependent variable) in 22 einkorn genotypes. The last column shows genotypic correlations $\left(r_{p h}\right)$ of independent variables with grain yield per plant

\begin{tabular}{|l|c|c|c|c|c|c|c|c|c|c|c|c|c|}
\hline \multicolumn{1}{|c|}{ Traits } & LSL & WSL & TNTP & NPTP & PH & SLWA & SLWOA & NSS & NGS & GWS & TGW & $\begin{array}{l}\text { Total } \\
\text { indirect } \\
\text { fffect }\end{array}$ & $\mathbf{r}_{\text {ph }}$ \\
\hline LSL & $\underline{\mathbf{0 . 0 1 8}}$ & -0.005 & 0.133 & -0.159 & -0.058 & -0.056 & -0.015 & 0.046 & 0.048 & 0.010 & 0.006 & -0.049 & -0.031 \\
\hline WSL & -0.001 & $\underline{\mathbf{0 . 0 7 9}}$ & $\mathbf{0 . 5 1 6}$ & $\mathbf{- 0 . 8 7 7}$ & -0.004 & -0.064 & 0.053 & -0.026 & -0.031 & -0.045 & -0.003 & -0.481 & -0.402 \\
\hline TNTP & -0.002 & -0.030 & $\underline{\mathbf{- 1 . 3 7 1}}$ & $\mathbf{1 . 8 4 8}$ & 0.064 & 0.072 & -0.047 & -0.007 & 0.025 & -0.147 & -0.004 & $\mathbf{1 . 7 7 2}$ & 0.401 \\
\hline NPTP & -0.002 & -0.036 & $\mathbf{- 1 . 3 2 9}$ & $\underline{\mathbf{1 . 9 0 7}}$ & 0.062 & 0.071 & -0.054 & -0.004 & 0.019 & -0.098 & -0.003 & $\mathbf{- 1 . 3 7 3}$ & $0.534 * *$ \\
\hline PH & 0.008 & 0.003 & $\mathbf{0 . 6 9 3}$ & $\mathbf{- 0 . 9 4 5}$ & $\underline{\mathbf{- 0 . 1 2 6}}$ & -0.023 & 0.149 & 0.009 & -0.036 & 0.137 & 0.003 & -0.002 & -0.128 \\
\hline SLWA & 0.004 & 0.019 & 0.377 & $\mathbf{- 0 . 5 1 9}$ & -0.011 & $\underline{\mathbf{- 0 . 2 6 1}}$ & 0.328 & -0.026 & -0.061 & -0.068 & -0.004 & 0.040 & -0.221 \\
\hline SLWOA & -0.001 & 0.008 & 0.121 & -0.197 & -0.036 & -0.163 & $\underline{\mathbf{0 . 5 2 5}}$ & -0.069 & -0.167 & -0.028 & -0.007 & -0.538 & -0.013 \\
\hline NSS & -0.008 & 0.021 & -0.103 & 0.068 & 0.011 & -0.068 & 0.364 & $\underline{\mathbf{- 0 . 1 0 0}}$ & -0.161 & -0.105 & -0.012 & 0.006 & -0.094 \\
\hline NGS & -0.004 & 0.010 & 0.143 & -0.150 & -0.019 & -0.067 & 0.370 & -0.068 & $\underline{\mathbf{- 0 . 2 3 7}}$ & 0.208 & -0.005 & $\mathbf{0 . 4 1 9}$ & 0.182 \\
\hline GWS & 0.000 & -0.005 & 0.306 & -0.284 & -0.026 & 0.027 & -0.022 & 0.016 & -0.075 & $\underline{\mathbf{0 . 6 5 7}}$ & 0.014 & -0.049 & $0.608^{* *}$ \\
\hline TGW & 0.006 & -0.011 & 0.299 & -0.281 & -0.021 & 0.051 & -0.200 & 0.061 & 0.059 & 0.491 & $\underline{\mathbf{0 . 0 1 9}}$ & $\mathbf{0 . 4 5 4}$ & $0.473 *$ \\
\hline
\end{tabular}

Direct effects obtained in path analysis showed that maximum positive direct effect on grain yield per plant was contributed mostly by number of productive tillers per plant (1.907), following by grain weight per spike (0.657) and spike length without awns (0.525). This means that a slight increase in one of these traits may directly contribute to grain yield. On the other hand, the maximum negative direct effect was exhibited by total number of tillers per plant $(-1.371)$, followed by spike length with awns $(-0.261)$ and number of grain per spike (-0.237). Total number of tillers per plant had positive indirect effect on yield grain per plant via number of productive tillers per plant, (1.907), respectively. Opposite, number of productive tillers per plant had negative indirect effect on yield grain per plant via total number of tillers per plant (-1.329). Width of second leaf and plant height had positive indirect effect on grain yield per plant via total number of tillers per plant $(0.516,0.693)$, while negative effect via number of productive tillers per plant $(-0.877,-0.945)$. Spike length with awns had negative indirect effect on grain yield per plant via number of productive tillers per plant (-0.519).

In order to remove effect of non-effective characteristics in regression model on grain yield, stepwise regression was used (45). In stepwise regression analysis, grain yield plant as dependent variable and other traits as independent variables were considered. The results showed that grain weight per spike, number of tillers per plant and total number of tillers per plant with $\mathrm{R}^{2}=85.30 \%$, had justified the maximum of yield changes (Table 5). According to Nasari et al. (46) existence of significant $\mathrm{R}$ square in a successful regression equation indicates the effectiveness of the traits to increase grain yield. It is observed that grain weight per spike was the most important character followed by number of productive tillers per plant and total number of tillers per plant. Particularly, $36.9 \%$ of the variation in grain yield was explained by grain weight per spike, $76.70 \%$ by grain weight per spike and 
DESHEVA G., et al.

number of productive tillers per plant altogether and $83.50 \%$ was contributed collectively by grain weight per spike, number of productive tillers per plant and total number of tillers per plant. The best prediction equation, based on the final step of stepwise regression analyses, was determined as follows:

GYP $=-2.033+6.411 * G W S+0.830 * N P T P-0.399 * T N T P$.

Table 5. Stepwise regression of grain yield (dependent variable) and other traits (independent variables) in einkorn wheat

\begin{tabular}{|c|c|c|c|c|c|c|c|c|c|c|c|c|c|}
\hline & \multirow{2}{*}{ Model } & \multicolumn{2}{|c|}{$\begin{array}{l}\text { Unstandardized } \\
\text { Coefficients }\end{array}$} & \multirow{2}{*}{$\begin{array}{c}\begin{array}{c}\text { Standardized } \\
\text { Coefficients }\end{array} \\
\text { Beta }\end{array}$} & \multirow{2}{*}{$\mathrm{t}$} & \multirow{2}{*}{ Sig. } & \multicolumn{3}{|c|}{ Correlations } & \multicolumn{2}{|c|}{ Collinearity Statistics } & \multirow{2}{*}{$\begin{array}{c}\mathrm{R} \\
\text { Square }\end{array}$} & \multirow{2}{*}{$\begin{array}{l}\text { Adjusted } \\
\text { R Square }\end{array}$} \\
\hline & & B & $\begin{array}{l}\text { Std. } \\
\text { Error }\end{array}$ & & & & $\begin{array}{l}\text { Zero- } \\
\text { order }\end{array}$ & Partial & Part & Tolerance & VIF & & \\
\hline \multirow{2}{*}{1} & (Constant) & 2.722 & 1.401 & & 1.942 & 0.066 & & & & & & \multirow{2}{*}{0.369} & \multirow{2}{*}{0.337} \\
\hline & GWS & 6.369 & 1.863 & 0.607 & 3.419 & 0.003 & 0.607 & 0.607 & 0.607 & 1.000 & 1.000 & & \\
\hline \multirow{3}{*}{2} & (Constant) & -2.466 & 1.261 & & -1.957 & 0.065 & & & & & & \multirow{3}{*}{0.767} & \multirow{3}{*}{0.743} \\
\hline & GWS & 7.364 & 1.173 & 0.702 & 6.276 & 0.000 & 0.607 & 0.821 & 0.694 & 0.978 & 1.023 & & \\
\hline & NPTP & .309 & .054 & 0.638 & 5.705 & 0.000 & 0.534 & 0.795 & 0.631 & 0.978 & 1.023 & & \\
\hline \multirow{4}{*}{3} & (Constant) & -2.033 & 1.101 & & -1.847 & 0.081 & & & & & & \multirow{4}{*}{0.835} & \multirow{4}{*}{0.808} \\
\hline & GWS & 6.411 & 1.072 & 0.611 & 5.980 & 0.000 & 0.607 & 0.816 & 0.572 & 0.874 & 1.144 & & \\
\hline & NPTP & 0.830 & 0.196 & 1.713 & 4.226 & 0.001 & 0.534 & 0.706 & 0.404 & 0.056 & 17.981 & & \\
\hline & TNTP & -0.399 & 0.146 & -1.123 & -2.730 & 0.014 & 0.401 & -0.541 & -0.261 & 0.054 & 18.506 & & \\
\hline
\end{tabular}

\section{CONCLUSION}

The present study showed the existence of wide ranges of variations for all of the traits among einkorn wheat genotypes. High heritability accompanied with moderate expected genetic advances in the case of number of spikelets per spike indicated that most likely the heritability was due to additive gene effect and selection may be effective in early generations for this trait. High values for the genetic advance and moderate values for the heritability in broad sense were also observed in the traits total number of tillers per plan and number of productive tillers per plant. Maximum positive direct effects on grain yield per plant were contributed mostly by number of productive tillers per plant and grain weight per spike, while the maximum negative direct effect was exhibited by total number of tillers per plant. Stepwise regression analysis also showed that grain weight per spike, number of tillers per plant and total number of tillers per plant had justified the maximum of yield changes.

\section{ABBREVIATION}

LSL - length of second leaf $(\mathrm{cm})$, WSL - width of second leaf $(\mathrm{cm})$, TNTP - total number of tillers per plant, NPTP - number of productive tillers per plant, $\mathrm{PH}$ - plant height $(\mathrm{cm})$, SLWA
- spike length with awn (cm), SLWOA - spike length without awn $(\mathrm{cm})$, NSS - number of spikelets per spike, NGS - number of grains per spike, GWS - grain weight per spike (g), GYP - grain yield per plant (g), TGW thousand grain weight $(\mathrm{g})$, MS - Mean squares, CV - coefficient of variation (\%). EV - Ecological variance, GV - Genotypic variance, $\mathrm{PhV}$ - Phenotypic variance, $\mathrm{PhCV}$ Phenotypic coefficient of variability, GCV Genotypic coefficient of variability, $\mathrm{H}$ Heritability (\%), GA - Genetic advance (\%) and GAM - Genetic advance in percentage of means $(\%)$

\section{REFERENCES}

1. Konvalina, P., Capouchová, I., Stehno, Z., Moudrý, J., Agronomic characteristics of the spring forms of the wheat landraces (einkorn, emmer, spelt, intermediate bread wheat) grown in organic farming. Journal of Agrobiology, 27(1):9-17, 2010.

2. Vasu, K., Singh, H., Singh, S., Chhuneja, P., Dhaliwal, H. S., Microsatellite marker linked to a leaf rust resistance gene from Triticum monococcum $\mathrm{L}$ transferred to bread wheat. Journal of Plant Biochemistry and Biotechnology, 10:127-132, 2001.

3. Dhaliwal, H. S., Chhuneja, P., Singh, I., Ghai, M., Goel, R. K., Garg, M., Keller, B., 
Röder, M., Singh K., Triticum monococcum L.- a novel source for transfer and exploitation of disease resistance in wheat. In: Proceedings of the 10th international wheat genetics symposium, Paestum, Italy, 346-349, 2003.

4. Sodkiewicz, W. and Strzembicka, A., Application of Triticum monococcum L. for the improvement of triticale resistance to leaf rust (Puccinia triticina). Plant Breeding, 123, 39-42, 2004.

5. Yao, G., Zhang, J., Yang, L., Xu, H., Jiang, Y., Xiong, L., Zhang, C., Zhang, Z., Ma, Z., Sorrells, M.E., Genetic mapping of two powdery mildew resistance genes in einkorn (Triticum monococcum L.) accessions. Theoretical and Applied Genetics, 114(2):351-358, 2007.

6. Jing Hai-Chun, Kornyukhin, D., Kanyuka, K., Orford, S., Zlatska, A., Mitrofanova, O. P., Koebner, R., Hammond-Kosack, K., Identification of variation in adaptively important traits and genome-wide analysis of trait-marker associations in Triticum monococcum L. Journal of Experimental Botany, 58(13), 3749-3764, 2007.

7. Chhuneja, P., Kaur, S., Garg, T., Ghai, M., Kaur, S., Prashar, M., Bains, N.S., Goel, R. K., Keller, B., Dhaliwal, H.S., Singh, K., Mapping of adult plant stripe rust resistance genes in diploid A genome wheat species and their transfer to bread wheat. Theoretical and Applied Genetics, 116:313-324, 2008.

8. Schmolke, M., Mohler, V., Hartl, L., Zeller, F. J., Hsam, S. L. K., A new powdery mildew resistance allele at the Pm4wheat locus transferred from einkorn (Triticum monococcum L.). Molecular Breeding, 29 (2), 449-456, 2012.

9. Stagnari, F., Codianni, P., Pisante, M., Agronomic and kernel quality of ancient wheat grown in central and southern Italy. Cereal Research Communications, 36:313326, 2008.

10.Abdel-Aal, E.-S.M., Young, J.C., Wood, P.J., Rabalski, I., Hucl, P., Falk, D., Frergeau-Reid, J., Einkorn: a potential candidate for developing high lutein wheat. Cereal Chemistry, 79, 455-457, 2002.

11.Grausgruber, H., Sailer, Ch., Ghambashidze, G., Bolyos1, L., Ruckenbauer, P., Genetic variation in agronomic and qualitative traits of ancient wheat. Genetic Variation for Plant Breeding, 19-22, 2004.

12.Frégeau-Reid, J., Abdel-Aal, E-SM, Einkorn: A potential functional wheat and genetic resource. In Abdel-Aal E-SM, Wood P (eds.): Speciality Grains for Food and Feed. Minnesota, American Association of Cereal Chemists Inc., 37-62, 2005.

13.Brannon, A.C, Ancient and alternative grains. Today's Dietitian, 9 (5), 10-11, 2007.

14.Hidalgo, A., Brandolini, A., Pompei, C., Piscozzi, R., Carotenoids and tocols of einkorn wheat (Triticum monococcum ssp. monococcum L.). Journal of Cereal Science, 44: 182-193, 2006.

15.Hidalgo, A. and Brandolini, A., Protein, ash, lutein and tocols distribution in einkorn (Triticum monococcum L. subsp. monococcum) seed fractions. Food Chemistry, 107:444-448, 2008.

16. Hidalgo, A. and Brandolini, A., Nutritional properties of einkorn wheat (Triticum monococcum L.). Journal of the Science of Food and Agriculture, 94(4):601-12, 2014.

17.Firouzian, A., Heritability and genetic advance of grain yield and its related traits in wheat. Pakistan Journal of Biological Science, 6 (24), 2020-2023, 2003.

18. Subhashchandra, B., Lohithaswa, H.C., Desai, S.A., Hanchinal, R.R., Kalappanavar, I.K., Math, K.K., Salimath, P.M., Assessment of genetic variability and relationship between genetic diversity and transgressive segregation in tetraploid wheat. Karnataka Journal of Agricultural Sciences, 22(1): 36-38, 2009.

19.Amin, M.R., Barma, N.C.D. and Razzague, M.A., Variability, heritability, genetic advance and correlation study in some quantitative characters in durum wheat. Rachis Newsletter, 11: 30-32, 1992.

20.Eid, M. H., Estimates of heritability and genetic advance of yield traits in wheat (Triticum aesivum L.) under drought conditions. International Journal of Genetics and Molecular Biology 1(7): 115 - 120, 2009.

21.Iqbal, M.Z. and Khan, S.A., Genetic variability, partial regression, co heritability studies and their implications in selection in selection of high yielding potato genotype. Pakistan journal of scientific and industrial research, 46: 123-125, 2003.

22. Shoukat, A.M., Mahboob, A.S., Bashir, A.A., Afzal, M., Study of genetic parameters in segregating populations of spring wheat. Pakistan Journal of Botany, 39(7): 2407-2413, 2007.

23. Abinasa, M., Amsalu, A., Geremew, B., Genetic variability, heritability and trait associations in durum wheat (Triticum turgidum L. var. durum) genotypes. African Journal of Agricultural Research, 6(17): 3972-3979, 2011. 
24.Khan, A.S., Ashfaq, M., Asad, M.A. A correlation and path coefficient analysis for some yield components in bread wheat. Asian Journal of Plant Sciences, 2: 582-584, 2003.

25.Khan, H., Rahman, H., Ahmed, H. and Ali, H., Magnitude of heterosis and heritability in sunflower over environments. Pakistan Journal of Botany, 1: 301-308, 2008.

26.Lidansky, T., Statistical methods in the biology and in the agriculture - Zemizdat, Sofia, 1988.

27.Singh, R.K., Chaudhary, B.D., Biometrical methods in quantitative genetic analysis. Kalyani Publ., New Delhi, 1985.

28. Brim, C.A., Johnson, H.W., Cockerham, C.C., Multiple selection criteria in soybean. Crop Science, 1: 187-190, 1959.

29. Dewey, R.D., Lu K.H., A correlation and path coefficient analysis of components of crested wheat grass seed production. Agronomy Journal, 51(9): 515-518, 1959.

30. Khokhar, M., Ilyas, M., Hussain, M., Zulkiffal, W., Sabir, S., Mahmood, M., Waqas, J., Anwar, J., Studies on genetic variability and inter-relationship among the different traits in wheat (Triticum aestivum L.). Krmiva, 52, Zagreb, 2; 77-84, 2010.

31.Alam, M.A., Khan1, A.A., Alam, M.K., Sarker, Z.I., Rahman, M.M., Variability and diversity studies in durum wheat (Triticum durum Desf.). Journal of Science and Technology, 11: 1-5, 2013.

32.Desheva, G. and Kyosev, B., Genetic diversity assessment of common winter wheat (Triticum aestivum L.) genotypes. Emirates Journal of Food and Agriculture, 27 (3), 283290, 2015.

33.Desheva, G., Cholakov, T., Variability, heritability and genetic progress for some yield components in common winter wheat genotypes (Triticum aestivum L.). Genetics and Plant Physiology, Conference "Plant Physiology and Genetics - Achievements and Challenges", 24-26 September 2014, Sofia, Bulgaria, Special Issue (Part 2), 4(3-4): 191200, 2014.

34.Desheva, G., Morphological and agronomical characterization of common wheat landraces (Triticum aestivum L.) from the National wheat collection of Bulgaria. Emirates Journal of Food and Agriculture, 26(2), 164169, 2014.

35. Kalimullah, S., Khan, J., Irfaq, M., Rahman, H. U., Gentetic variability, correlation and diversity studies in bread wheat (Triticum aestivum L.) germplasm. Journal of Animal and Plant Sciences, 22(2):330-333, 2012.

36. Kumar, N., Markar, Sh., Kumar, V., Studies on heritability and genetic advance estimates in timely sown bread wheat (Triticum aestivum L.). Bioscience Discovery, 5(1):6469, 2014.

37.Deshmukh, S.N.N., Basu, M.S., Reddy, P.S., Genetic variability, character association and path coefficient analysis of quantitative traits in Viginia bunch varieties of groundnut. Indian Journal of Agricultural Sciences, 56: 516-521, 1986.

38. Dyulgerova, B. and Valcheva, D., Heritability, Variance Components and Genetic Advance of Yield and Some Yield Related Traits in Barley Doubled Haploid Lines. Turkish Journal of Agricultural and Natural Sciences, Special Issue: 1, 614-617, 2014.

39. Kyosev, B. and Desheva, G., Study on variability, heritability, genetic advance and associations among characters in emmer wheat genotypes (Triticum dicoccon Schrank). Journal of Bioscience and Biotechnology, SE/ONLINE: 221-228, 2015.

40. Mesele, A., Wassu, M., Tadesse, D., Estimation of heritability and genetic advance of yield and yield related traits in bread wheat (Triticum aestivum L.) genotypes at Ofla district, Northern Ethiopia. International Journal of Plant Breeding and Genetics, 10: 31-37, 2016.

41. Ajmal, S.U., Zakir, N., Mujahid, M. Y., Estimation of Genetic Parameters and Character Association in Wheat. Journal of Agricultural and Biological Science, 1 (1):1518 (2009).

42. Farshadfar, E. and Estehghari, M. R., Estimation of genetic architecture for agromorphological characters in common wheat. International Journal of Biosciences, Vol. 5, No. 6, p. 140-147, 2014.

43. Chhibber, S.and Divya J., Inter correlation studies among yield and its contributing traits in bread wheat genotypes grown in Haryana, India (Triticum aestivum L.). International Journal of Current Research and Review, 6(12): 12-18, 2014.

44. Abd El-Mohsen, A., and Abd El-Shafi, M. A., Regression and path analysis in Egyptian bread wheat. Journal of Agri-Food and Applied Sciences, 2(5): 139-148, 2014.

45.Hannachi, A., Fellahi Zine El, A., Bouzerzour, H., Boutekrabt, A., Correlation, Path Analysis and Stepwise Regression in Durum Wheat (Triticum durum Desf.) under Rainfed Conditions. Journal of Agriculture and Sustainability, 3 (2), 122-131, 2013.

46. Nasari, R., Kashani, A., Paknejad, F., Vazan, S., Barary, M., Correlation, path analysis and stepwise regression in yield and yield component in wheat (Triticum aestivum L.) under the temperate climate of Ilam province, Iran. Indian Journal of Fundamental and Applied Life Sciences, 4 (4):188-198, 2014. 